\title{
ANALISIS SKENARIO TELEVISI DAN TV PENDIDIKAN

\section{Abstrak}

Kualitas skenario memiliki kontribusi terhadap mutu acara TVI film, termasuk program pendidikan. Hal ini penting karena kenyataanya produk TV/film lokal kita masih sulit bersaing dengan produk asing. Tulisan ini melakukan analisis/kajian literatur dan empirik terhadap skenario TV termasuk program pendidikan. Hasil analisis dari beberapa sumber dan pengalaman empirik diketahui bahwa kelemahan skenario antara lain: keterbatasan wawasan penulis terhadap substansi tuntutan skenario, alur cerita kurang variatif dinamis, penokohan yang terkesan datar, penggunaan bahasa, serta penghargaan terhadap penulis yang masih kurang. Sementara itu penulisan skenario untuk program pendidikan di samping aspek tadi, penulis terjebak pada penyampaian substansi materi pembelajaran sehingga mengabaikan aspek estetika, memaksakan membuat alur cerita dari substansi materi yang kurang pas, serta memindahkan ruangan kelas ke layar TV. Oleh karena itu, untuk memperoleh hasil skenario yang bermutu perlu kesadaran semua pihak, bahwa peningkatan mutu acara TV lokal agar bisa bersaing dengan produk asing harus dimuali dengan skenario yang bermutu.

\section{Kata Kunci:}

skenario, televisi, televisi pendidikan, penulis skenario,

*) Drs. Oos M. Anwas, M.Si, adalah Penulis Skenario TV, Peneliti Bidang Pendidikan, bekerja di Pustekkom Depdiknas. oos_anwas@plasa.com 


\section{A. PENDAHULAN}

Kenapa peristiwa 11 Sepetember yang menghancurkan menara kembar WTC di Amerika Serikat hingga kini yang dicari adalah siapa pembuat skenarionya. Siapa pembuat skenario kerusuhan di Poso. Siapa skenario pembobolan bank BNI, dan sebagainya. Ini menunjukan betapa pentingnya peran sang pembuat skenario. Begitu pula pembuat skenario film/sinetron, ia adalah otak yang menggerakkan sutradara, pemain, editor, audioman, dan crew lainnya sehingga menjadikan sebuah tontonan yang menarik.

Adalah Eros Jarot (2002) seorang sutradara senior yang mengatakan bahwa skenario itu adalah jantungnya film. Ibarat diri manusia, kalau jantungnya tidak baik dapat mempengaruhi keseluruhan kinerja tubuh. Hal ini menunjukan betapa pentingnya skenario dalam sebuah film/televisi. Melalui skenario, sang sutradara, pemain dan crew lainnya mendapatkan acuan mulai dari alur cerita, penokohan, dialog, termasuk gerak tubuh sang pemain. Singkatnya, dalam skenario ini telah tergambar jelas alur cerita visual dan audio yang diinginkan dalam sebuah film/sinetron.

Kenapa film nasional kini seolah mati suri? Jika satu dua munculpun, sulit untuk bisa menandingi film asing. Sebaliknya, film asing (Amerika dan India) makin membanjiri semua bioskop kita termasuk dalam format VCD. Anehnya, film import ini makin diminati masyarakat. Padahal nuansa film asing memiliki perbedaan dengan budaya kita, sehingga agak sulit untuk dipahami. Idealnya film pribumi-lah yang harus lebih disukai. Keragaman budaya bangsa dan ikatan kesamaan rumpun budaya akan menjadi daya tarik dan memudahkan dalam mencerna film nasional. Banyak faktor yang menjadi penyebab semua itu. Tetapi salah satunya yang mempunyai andil besar adalah kelemahan penulis skenario.

Memang menulis kenario tidaklah mudah, memerlukan teknik dan keahlian dalam menulisnya. Namun kemampuan menulis saja tidaklah cukup. Beberapa rekan wartawan misalnya yang sudah terbiasa menulis, belum tentu ia bisa membuat skenario. Saya 
mempunyai beberapa teman wartawan yang tentu saja sudah terbiasa menulis ternyata tidak sanggup untuk menulis skenario. Pernah beberapa orang dicoba menulis, hasilnya masih jauh dari yang diharapkan. Kalau demikian, apakah kita kekurangan penulis skenario. Sebenarnya banyak penulis skenario yang kita miliki, sebut saja Eddy D. Iskandar, Garin Nugroho, dan lainnya. Begitupun karya mereka tidak sedikit yang telah mendapatkan penghargaan internasional.

Kali ini kita coba mengkaji skenario film/TV. Bagaimana kesulitan sang penulis ketika memulai menulis kenario film/sinetron? la akan dihadapkan pada format sajian, menyusun cerita dan membaginya dalam berberapa scene yang sistematis, memvisualisasikan ide dalam bentuk serangkaian gambar bergerak, termasuk illustrasi musik dan sound effect untuk menguatkan sebuah adegan.

\section{B. HAKEKAT SKENARIO}

Skenario merupakan panduan bagi sutradara, pemain, crew film, termasuk produser. Dialog, gerakan tubuh, suasana, sound effect, dan lainnya telah tertuang dalam skenario. Tugas crew adalah bagaimana menterjemahkan skenario tersebut.

Mengingat pentingnya peran skenario, bisa dikatakan bahwa jika skenarionya bagus maka lebih berpeluang film-nya juga bagus. Begitu juga sebaliknya. Walaupun tidak menjamin pula skenario bagus, filmnya akan bagus pula karena skenario selanjutnya akan diterjemahkan oleh sutradara ke dalam sebuah adegan. Begitu pula aspek crew lainnya.

Memang membuat acara film merupakan pekerjaan sebuah tim. Semua komponen harus kompak dan saling menunjang dalam menghasilkan buah karya yang berkualitas. Kerjasama tim ini semuanya mengarah pada skenario, menterjemahkan skenario agar menjadi tontonan yang menarik dan bermutu. Jadi tidak berlebihan jika dikatakan skenario akan banyak memberikan warna terhadap hasilnya kelak. Oleh karena itu, skenario harus dibuat sebaik-baiknya. 
Permasalahannya adalah bagaimana skenario yang bagus tersebut. Menurut seorang produser film, Shanty Harmayan (2002), skenario yang baik adalah yang bisa menerjemahkan sebuah cerita sehingga ia bisa menjelaskan apa yang diutarakan. Sementara itu Eddy D. Iskandar (1999) mengibaratkan membuat film seperti menjahit pakaian. Fungsi skenario adalah sebagai polanya atau rancangannya, sehingga melalui pola tersebut akan tergambar bentuk bajunya nanti. Begitu pula skenario, dituntut bisa menggambarkan sebuah film.

Skenario tidak hanya bahasa verbal, tapi yang lebih penting bagaimana sang penulis menuangkan dalam bahasa visual. Menurut Eddy D. Iskandar (1999), menulis skenario tidak sebebas menulis sebuah karya sastra, sebab ada aturan-aturan tertentu yang mesti dipatuhi. Seorang penyair atau pengarang bisa bebas berkhayal, atau bisa melontarkan ungkapannya dalam beragam gaya bahasa. Sedangkan bagi penulis kenario, ruang geraknya dibatasi oleh hukum-hukum teknis.

Tidak sedikit pula yang menganggap menulis skenario sama dengan menulis naskah drama. Dalam hal tertentu keduanya memang sama, tetapi memiliki perbedaan yang mendasar. Misalnya dalam sebuah drama, dialog merupakan sumber informasi utama. Para penonton lebih banyak menangkap isi cerita melalui dialog. Sedangkan sebuah film, dialog fungsinya hanya sebagai pelengkap dari visualisasi. Penonton bisa menangkap isi cerita/ pesan melalui adegan visual. Jadi, salah satu kriteria skenario yang bagus adalah kemampuan penulis menuangkan ide/gagasannya dalam sebuah adegan visual. Sebaliknya, jika naskah film/televisi didominasi oleh dialog, sangatlah disayangkan. Kekuatan media film/televisi terletak pada aspek visual yang dilengkapi dengan unsur gerak. 


\section{ANALISIS PENULISAN SKENARIO}

\section{Wawasan yang Cukup}

Menjadi penulis skenario dituntut memiliki kemampuan dalam hal menulis, baik dalam bahasa dialog maupun bahasa visual. Jika kita perhatikan beberapa film asing, ketika menyajikan adegan medis, aktor yang menjadi sang dokter begitu pasih menguasai ilmu kedokteran, mengetahui seluk-beluk penyakit, diagnosa, hingga penanganannya seolah-olah ia benar-benar sebagai dokter. Hal ini bukan berarti sang aktor tahu ilmu kedokteran, akan tetapi naskahnya begitu lengkap. Sang penulis naskah juga bukan seorang dokter bahkan mungkin ia tidak memiliki dasar-dasar ilmu kedokteran. Sebagi penulis, ia berkewajiban menggali keilmuan yang diperlukan sesuai tuntutan alur cerita.

Sebaliknya, film atau sinetron kita terkesan dangkal. Adegan atau dialog yang sifatnya teknis terkesan sekilas dan begitu cepat. Mungkin saja penulis naskahnya menguasai ilmu film, akan tetapi ia tidak menguasai wawasan dan budayanya. Yang lebih parah, penulis malas untuk mendalami keilmuan sesuai tuntutan naskah. Akibatnya skenario, baik bahasa verbal maupun visual, menjadi dangkal dan kurang menarik.

Menurut Eros Jarot (2002) penulis skenario harus memiliki kekayaan batin, kekayaan wawasan, dan kekayaan kata-kata. Kalau penulis skenario minimal dia harus punya disiplin ilmunya. la juga harus mengenal wilayah, menenal juga budaya, dan mengenal disiplin.

Jika kita perhatikan, beberapa tayangan film/sinetron sering menonjolkan salah satu budaya tertentu. Penonjolan budaya ini seringkali justru menjadi daya tarik. Misalnya sinetron "Si Doel Anak Sekolahan" yang ditayangkan RCTI menonjolkan budaya 
Betawi. Sinetron ini cukup berhasil dan pernah mencapai rating tertinggi. Di sini peran penulis skenario sangat besar. la tampak memahami betul budaya masyarakat Betawi. la juga bisa menuangkan sebuah realitas keseharian suku Betawi di tengahtengah hiruk-pikuk keramaian kota metropolitan. Sang penulis bisa menuangkan ke dalam skenario kebiasaan masyarakat Betawi mulai dari nuansa almosfir masyarakat, logat bicara, pakaian, rumah, dan lainnya sehingga tayangan ini benar-benar menggambarkan realitas keseharian masyarakat Betawi. Keberhasilan ini karena sang penulis memiliki wawasan dan kekayaan yang cukup tentang budaya Betawi.

Stasiun TPI misalnya kini menayangkan sinetron kisah nyata "Bukan Hanya Mimpi". Sinetron ini menyajikan kisah nyata perjuangan pengusaha kecil dari berbagai daerah yang dibuat dalam format dramatisasi. Di sini, penulis naskah dituntut untuk memahami tidak hanya satu budaya tapi berbagai budaya sesuai dengan asal tokoh. Bagaimana bisa menulis dengan baik jika sang penulis tidak memahami budaya Sulawesi Selatan misalnya ketika ia menulis dramatisasi perjuangan usaha tokoh dari daerah tersebut? Nampaknya sangat sulit jika acara seperti ini ditulis oleh satu atau dua orang penulis karena mereka harus memahami betul budaya berbagai suku yang cukup kompleks. Oleh karena itu, acara seperti ini dibutuhkan banyak penulis yang tidak hanya memiliki wawasan kewirausahaan tetapi juga memahami budaya yang sesuai dengan sang tokoh.

\section{Alur Cerita}

Ketika kita sedang menonton film, dalam hitungan beberapa menit saja sudah bisa ditebak alur cerita, sehingga menjadi tidak menarik. Misalnya dalam cerita-cerita film silat, selalu diawali dengan tindakan kekerasan atau penganiayaan terhadap sang tokoh atau keluarga tokoh. Sang tokoh yang biasanya masih kecil menyimpan dendam. Kemudian, ia berguru hingga menginjak dewasa. Di akhir cerita sang tokoh membalas dendam 
keluarganya atau menumpas kejahatan dengan ilmu yang dimiliki hasil bergurunya. Begitu seterusnya. Alur cerita seperti ini banyak kita jumpai dalam berbagai film kita, sehingga daya tarik film menjadi menurun.

Alur cerita sangat penting. Alur cerita harus bisa dipahami dan rasional. Tetapi yang lebih penting, alur cerita bisa membuat penonton tertarik, penasaran untuk menonton hingga akhir cerita. Di sini kemampuan sang penulis untuk mengolah alur cerita menjadi sebuah daya tarik tersendiri. Eddy D. Iskandar (1999) menegaskan untuk membuat daya tarik alur cerita, tidak harus $A, B, C, D$, s.d. Z. Bisa saja cerita dimulai dari $D$, lalu $A$, $B, C$ dan seterusnya. Atau bisa juga $D, E, E, A, L$, dan seterusnya.

Singkatnya, urutan cerita bisa dimainkan, asalkan penulis tetap menonjolkan benang merah sebuah cerita, sehingga penonton bisa menangkap alur cerita dan menarik untuk ditonton. Untuk menjadikan daya tarik, biasanya penulis mencari scene yang paling menarik. Scene ini ditempatkan di awal cerita. Dengan cara seperti ini penonton akan tertarik dan menjadi penasaran untuk mengikuti terus hingga acara selesai.

\section{Karakteristik Tokoh}

Dalam berbagai diskusi tentang film Indonesia, salah satu kelemahannya adalah dialog-dialog yang terkesan seragam. Dialog yang dilontarkan sang tokoh tidak sesuai dengan karakteristiknya. Misalnya, petani di pedesaan berbicara dengan gaya intelek, dialog anak SD seperti remaja bahkan orang tua, gaya bicara pembantu rumahtangga sama majikannya, atau seorang guru berbicara seperti pengusaha. Kejadian seperti ini rasanya tidak sulit dijumpai dalam adegan film atau sinetron kita.

Saya yakin bahwa penulis sebelumnya sudah menentukan karakteristik setiap tokoh. Hanya saja ketika menulis penokohan itu kurang dijiwai secara mendalam. Akibatnya ia tidak sadar 
membuat dialog yang terkesan sejajar. Di sinilah tuntutan sang penulis untuk bisa menjadi berbagai karakter secara konsisten.

\begin{tabular}{|c|c|c|}
\hline $\begin{array}{l}\text { Pen } \\
\text { pko } \\
\text { berik }\end{array}$ & 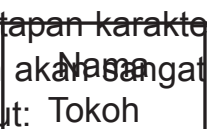 & 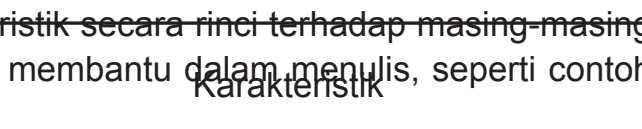 \\
\hline 1 & Dewi & wanita cantik selalu berjilbab, taat \\
\hline Kara & teristik tokoh & $\begin{array}{l}\text { beragama, lembut, penyayang, usia } \\
\text { sekitar } 25 \text { tahun. }\end{array}$ \\
\hline 2 & Mona & $\begin{array}{l}\text { wanita cantik dan seksi, senang } \\
\text { bersolek, manja, cengeng, usia sekitar } \\
22 \text { tahun. }\end{array}$ \\
\hline 3 & Borokokok & $\begin{array}{l}\text { pria, jail, suka bercanda, polos, usia } \\
\text { sekitar } 26 \text { tahun. }\end{array}$ \\
\hline 4 & Amran & ayah yang rajin bekerja keras, agak \\
\hline
\end{tabular}

Penetapan karakteristik tokoh seperti di atas akan sangat membantu penulis dalam membuat skenario. Ketika menulis tokoh si Borokokok misalnya, ia bisa membayangkan bagaimana kejailan sang tokoh, kebiasaan berbicara, gerak tubuh, atau kita ciptakan sendiri logat atau ciri tertentu yang menunjukan jati diri yang bersangkutan. Begitu pula ketika menulis tokoh Dewi atau tokoh lainnya, penulis berpedoman pada acuan yang telah diietapkan sebelumnya.

Namun dalam kenyataanya, menjiwai karakter untuk dituangkan dalam sebuah adegan atau dialog tersebut tidak mudah. Penulis harus benar-benar menjiwai masing-masing karakter. Bisa dibayangkan seorang penulis seolah dirinya memerankan berbagai karakter yang berbeda. Kadang-kadang secara tidak sadar, ia menulis adegan atau dialog dengan nuansa yang hampir sama terhadap tokoh yang karakternya beda. Di sini penulis harus bisa mengibaratkan dirinya sebagai 
karakter yang baik, jahat, lucu, antagonis, tokoh ulama, tokoh masyarakat, dan sebagainya. la harus konsisten dengan karakterer tersebut dari awal hingga akhir cerita, dan kembali pada pertanyaan semula, apakah penulis memiliki wawasan yang cukup tentang berbagai karakter sang tokoh sesuai tuntutan naskah.

\section{Bahasa}

Eddy D. Iskandar (1999) menegaskan bahwa meskipun pernah ada film yang sama sekali tidak menggunakan dialog, tapi dialog dalam film tetap merupakan salah satu unsur terjalinnya komunikasi dengan masyarakat penonton. Namun menurutnya dalam dialog, bahasa yang penting adalah dialog yang mudah dicerna penonton. Oleh karena itu perlu dipertimbangkan segmentasi penonton dalam hal penguasaan bahasa. Perlu dihindari kata-kata atau istilah yang sulit dipahami khalayak. Kadang-kadang dialog menjemukan. Dialog sebuah film akan menarik apabila menggunakan kalimat yang padat dan wajar.

Bahasa dialog juga terkait dengan karakter dan status sosial sang tokoh. Bahasa petani di pedesaan akan berbeda dengan bahasa seorang ulama misalnya, walaupun mereka berasal dari satu daerah. Begitu pula dialog mahasiswa akan berbeda dengan bahasa yang digunakan oleh santri sekalipun usia mereka sebaya.

Logat atau dialek suatu daerah seringkali menjadi daya tarik dan ciri atau identitas asal sang tokoh. Dialog sang tokoh yang menggunakan kata; teh, mah, euleuh-eleuh, beu, menggambarkan bahwa tokoh tersebut berasal dari Sunda. Begitu pula kata mas, monggo, inggih dari Jawa; ucok, horas, bah, dari Batak; atau lu, gua, enyak, babe, engkong, hajar, dari Betawi. Yang menarik, kadang-kadang film/sinetron yang menceritakan realitas masyarakat Sulawesi Selatan misalnya tetapi dalam dialog muncul kata-kata elu, babe, gua dan 
sebagainya.

\section{Aturan Penulisan}

Menulis skenario film memiliki aturan. Hal ini terutama untuk memudahkan sutradara atau pihak lain yang berkepentingan dengan skenario tadi sehingga tidak terjadi salah penafsiran. Ada kalanya penulis yang terjebak dengan aturan penulisan yang ditetapkan oleh lembaga atau pemesan skenario. Akibatnya ia terjebak oleh aturan tersebut, sementara kreativitas yang jauh lebih penting terabaikan.

Secara umum, Eddy D. Iskandar (1999) membagi dua bentuk penulisan, yaitu pertama, penulisan skenario yang menggunakan istilah camera distance (jarak kamera) secara rinci, seperti: close up, long shot, medium shot, panning shot, low angle, zoom in, zoom out, dll. Kedua, yang tidak mencantumkan istilah-istilah tersebut, tetapi tetap menggunakan transisi waktu (pagi, sore, siang, malam) untuk tiap perpindahan atau babak.

Di bawah ini adalah contoh penulisan skenario bentuk pertama, yang menggunakan istilah jarak kamera. Skenario ini ditulis oleh sutradara Frank K. Rorimpandey yang berjudul "Setitik Embun" scene 22.

\section{EXTERIOR SEBUAH TAMAN- PAGI}

PANNING SHOT, PANORAMA sebuah taman yang indah. Bunga-bunga merekah. Warna -warni. Pada suatu sudut CAMERA HOLD dan ZOOM IN to MS SEPASANG KAKI REMAJA yang tak lain adalah kedua tokoh kita dalam cerita ini: KARTIKA DAN IMAN.

CATATAN:

Pada saat PANNING SHOT gambar dicetak ONE TONE COLOR pada saat CAMERA mulai ZOOM IN TO MS KARTIKA dan IMAN 
Dalam penulisan skenario di atas, sutradara seolah telah dipatok secara baku untuk melaksanakan perintah tersebut. Kreativitas sutradara cenderung dibatasi oleh aturan itu. Oleh karena itu, penulisan gaya seperti ini seharusnya hanya ditulis oleh penulis yang segaligus juga menjadi sutradaranya. Begitu pula sang penulis (bukan sutradara) jika diminta menulis model penulisan seperti ini, pikirannya akan tersita mengingat atau mencari istilah kamera dalam menuangkan idenya. Padahal yang lebih penting bagi sang penulis adalah menuangkan kreativitas seni dan wawasannya. Masih untung kalau penulis hafal. Jika tidak atau salah menuliskan istilah akibatnya skenario akan diterjemahkan berbeda dengan maksud penulis.

Bentuk penulisan kedua adalah yang tidak terikat dengan ketentuan teknis jarak kamera, misalnya skenario yang ditulis Oos M. Anwas, sutradara Anaitullah dalam sinetron "Bukan Hanya Mimpi" produksi TPI (2004) episode Belut Plamboyan.

\section{Scane 01. EXT. Pesawahan - Pagi}

Pemain: Komalasari, Maman

Keindahan alam pegunungan dan hamparan pesawahan di pagi hari. Beberapa petani dengan giat bekerja di sawah. Kamera terfokus pada seorang petani (Komalasari) menggunakan penutup kepala, sedang memasang Bubu untuk menangkap Belut di tengah sawah. Sekali-sekali kelapanya menunduk terhalang oleh tanaman padi.

Sementara itu tak jauh dari tempat itu, Maman dengan tatapan curiga mengintip perilaku Komalasari.

MAMAN (VO):

Ini pasti pencurinya.... Pantesan ikan saya sering hilang. 
Tiba-tiba Maman sudah di parit sawah dekat Komalasari, melotot, dan membentak sambil tolak pinggang.

\section{MAMAN:}

Hai, maling, bangsat, keur naon siah? Maling lauk?

Komalasari kaget, tidak sempat menjawab. la malah berlari ke tengah sawah. Maman makin marah, lalu mengejarnya sambil berteriak.

\section{MAMAN:}

Maling.... bangsat....!, bangsat lauk!

Komalasari makin ketakutan, berlari di sekitar sawah sambil menangis dan minta tolong. Tangannya memegang bubu. Maman makin bernafsu mengejarnya. Akibatnya tanaman padi rusak berat.

\section{KOMALASARI:}

Bukan, saya bukan maling! Aduh,... tulung..... tulung...!

\section{MAMAN:}

Ngaku bangsat, berhenti!. Kamu maling lauk.

Komalasari tersudut di pinggir petakan sawah. Dengan cepat ia membuka tutup kepalanya. Maman yang sudah siap memukul terkejut, ternyata yang dikejarnya adalah lbu Komalasari, tokoh perempuan yang disegani di desa itu. Dengan nafas ngos-ngosan, Komalasari berusaha menjelaskan duduk persoalanya.

\section{CUT TO}

Aturan penulisan skenario memang perlu diperhatikan oleh penulis. Maksudnya supaya ada kesamaan antara penulis 
dengan sutradara, produser, dan crew lainnya. Bagi penulis yang penting adalah bagaimana menuangkan wawasan dan kreativitasnya agar skenario bisa menarik. Begitu pula sutradara bisa berkreasi sehingga skenario dapat menjadi petunjuk dan memudahkan untuk menghasilkan sebuah karya seni yang berkualitas.

\section{Non Teknis}

Aspek non teknis lain yang memiliki kontribusi terhadap lemahnya kualitas skenario TV adalah masih lemahnya penghargaan terhadap penulis naskah. Berdasarkan pengamatan penulis, masih kecil penghargaan (salary) yang diberikan kepada penulis naskah. Akibatnya kurang memacu para penulis untuk berinovatif dan lebih celaka kecenderungan penulis lebih mengutamakan kuantitas skenario daripada kualitasnya. Di sini, perlu ada semacam kesadaran antara pihak yang berkepentingan untuk memahami pentingnya aspek ini. Di sisi lain, penulis skenario juga dituntut untuk menonjolkan profesionalisme. Penghargaan sebuah karya tulis sesungguhnya tidak bisa hanya diukur dari honor yang diterima ketika selesai menulis skenario. Kepuasan ini akan jauh lebih berharga ketika karyanya ditonton banyak orang dan berdampak positif. Inilah karya seni yang bisa dinilai pantas oleh orang yang mengerti sebuah seni.

\section{Skenario Program Pendidikan}

Daniss McQuel dan Sven Windahl (1996) dalam buku Communication Models for the Study of Mass Communication menjelaskan model psikologi Comstoc tentang efek televisi terhadap orang perorangan. Ditegaskannya bahwa media TV tidak hanya mengajarkan tingkah laku, tetapi juga tindakan sebagai stimulus untuk membangkitkan tingkah laku yang dipelajari dari sumber-sumber lain. Ini menunjukan bahwa media TV memiliki kekuatan yang ampuh (powerful) bagi pemirsanya, termasuk untuk keperluan pendidikan 
(pembelajaran).

Banyak penelitian yang telah dilakukan dalam pemanfaatan media televisi/film untuk pembelajaran. Misalnya penelitian yang dilakukan oleh Dewan Sekolah Anaheim (1963) (dalam Wilkinson 1994). Salah satu kesimpulan penelitian ini adalah dari 23 perbandingan antara belajar dengan televisi ditambah dengan pengajaran di kelas yang biasa, dengan kelompok yang hanya belajar di ruang kelas biasa saja, 11 kelompok menunjukkan bahwa kelompok televisi lebih unggul dengan derajat kepercayaan 0,5 dan tak satupun perbandingan yang menunjukkan hasil yang lebih baik pada kelompok ruang kelas biasa.

Yang menarik adalah hasil penelitian terhadap program televisi instruksional yang terkenal seperti Sesame Street yang dilakukan oleh Ball dan Bogatz (1970). Penelitian ini mengambil sampel besar mewakili anak-anak di empat geografis Amerika Serikat. Hasilnya ditemukan bahwa semakin banyak anak-anak nonton program tersebut, bertambah banyak mereka belajar dari apa yang dimaksudkan diajarkan oleh program tersebut, yakni huruf-huruf, angka, bentuk, memilih, klasifikasi, dan sebagainya.

Uraian di atas menunjukan bahwa media televisi dapat diandalkan sebagai salah satu media pembelajaran. Media televisi/video memiliki karakter media yang bisa menyajikan pesan audio visual dan unsur gerak. Dengan karakter seperti ini, pesan-pesan pembelajaran yang sifatnya jauh, cepat, benda kecil, besar, sebuah proses, warna, bunyi/suara, dan sebagainya dapat didesain untuk disajikan melalui media ini dalam membantu guru dan siswa mencapai hasil pembelajaran yang lebih optimal.

Televisi atau film pendidikan dirancang secara khusus (by design) untuk keperluan pembelajaran. Rancangan ini termasuk penulisan skenario. Pengalaman empirik penulis 
dalam penulisan skenario pendidikan prinsipnya sama. Perbedaanya adalah dalam skenario pendidikan, selain unsur kemenarikan, substansinya harus tercapai sesuai tujuan. Di sinilah kesulitan sang penulis. Membuat skenario yang menarik tidaklah mudah, di satu sisi tuntutan harus menarik, tetapi di sisi lain dituntut pula untuk menyampaikan substansi materi pembelajaran yang benar dan sesuai tujuan pembelajaran.

Dalam program pendidikan, unsur kemenarikan dan substansi materi ini merupakan dua sisi mata uang yang tak bisa dipisahkan. Perbandingan kedua aspek tersebut juga tidak ada acuan yang jelas. Di sinilah penulis harus bisa mengestimasi perbandingan tersebut. Namun jika kita perhatikan karakter medianya, apabila menulis media TV (tentu untuk disiarkan), aspek daya tarik perlu ditonjolkan. Hal ini berkaitan dengan ketatnya persaingan acara TV. Jika acara TV pendidikan tidak menarik, siapa yang mau nonton. Tentu pemirsa akan memindahkan chanelnya kepada acara yang lebih disukainya. Sebaliknya, jika menulis skenario untuk program video, di sini penulis bisa leluasa untuk menuliskan substansi materi sesuai tujuan pembelajaran. Unsur kemenarikan bisa sedikit diabaikan karena penonton video ini memiliki kesiapan mental untuk menonton. Singkatnya, menarik atau tidak, mereka pasti menonton.

Aspek lain menurut pengamatan penulis dalam penulisan naskah TV program pendidikan kadang-kadang penulis terjebak pada aspek penyampaian materi. Yang penting substansi materi sudah sampai, sedangkan aspek kemenarikan terabaikan. Ada pula penulis yang memaksakan materi pelajaran dibuat alur cerita seperti layaknya sinetron. Akibatnya cerita terkesan datar dan sangat miskin dengan adegan konflik. Padahal kekuatan sebuah format drama sangat ditentukan dengan konflik. Tidak sedikit penulis yang kehabisan akal 
sehingga memindahkan ruangan kelas ke dalam layar TV. Adegan yang ditulis dalam naskah hampir sama dengan adegan guru ketika menjelaskan materi pelajaran pada siswanya di depan kelas. Ini sungguh disayangkan, karakteristik media TV sebagai media pembelajaran yang bisa menyajikan aspek audio visual ini tidak bisa dioptimalkan.

Memang penulis naskah TV pendidikan/pembelajaran dituntut untuk kreatif dan inovatif. Unsur-unsur penulisan naskah di atas seperti wawasan, alur cerita, karakteristik tokoh, bahasa, aturan penulisan, dan aspek lain dalam penulisan naskah TV perlu diperhatikan seperti layaknya membuat sinetron. Hanya saja di sini penulis harus bisa memainkan dua aspek yaitu menarik dan substansi materi tercapai.

\title{
E. KESIMPULAN DAN SARAN
}

\begin{abstract}
Kesimpulan
Sebuah skenario termasuk untuk program pendidikan memiliki dampak terhadap baik buruknya acara TV/film. Skenario ini akan menuntun sutradara, pemain, produser, dan crew lainya untuk membangun sebuah acara yang enak ditonton dan berdampak positif. Oleh karena itu, salah satu faktor lemahnya program TV/ film kita dibandingkan dengan produk asing adalah karena kelemahan dalam pembuatan skenario.
\end{abstract}

Beberapa kelemahan penulisan skenario antara lain: aspek keterbatasan wawasan penulis terhadap substansi tuntutan skenario, alur cerita kurang variatif dinamis, penokohan yang terkesan datar untuk semua tokoh, penggunaan bahasa yang kurang pas, serta penghargaan terhadap penulis yang masih kurang.

Khusus dalam naskah program pendidikan/pembelajaran, selain aspek-aspek di atas beberapa kesalahan yang dilakukan dalam 
penulisan skenario di antaranya: penulis terjebak pada penyampaian substansi materi pembelajaran sehingga mengabaikan aspek estetika, memaksakan membuat alur cerita dari substansi materi yang kurang pas, serta memindahkan ruangan kelas ke layar TV.

\section{Saran}

Untuk mendapatkan skenario yang baik dituntut semua pihak mulai dari produser, sutradara, pemain, crew, serta pihak-pihak terkait lainnya untuk menyadari akan pentingnya skenario yang berkualitas. Kualitas sebuah acara TV/film dimulai dengan skenario yang bermutu. Dengan cara ini diharapkan penghargaan terhadap sebuah karya tulis khususnya skenario dapat meningkat.

Secara teknis penulis naskah perlu menyadari kelemahan yang dilakukan dalam penulisan skenario, mulai dari perlunya meningkatkan wawasan sesuai tuntutan topik bahasan dalam skenario, alur cerita yang variatif, penokohan yang sesuai dengan karakter, bahasa yang tepat, dan penguasaan aturan penulisan. Penulis juga perlu menyadari bahwa penghargaan terhadap karyanya tidak hanya diukur dengan salary yang diterima, tetapi ada kepuasan batin terhadap hasil karya seninya bisa ditonton banyak orang dan bermutu.

Penulis naskah program pendidikan juga perlu untuk memiliki sikap mental tersebut. Mereka juga dituntut untuk bisa menyatukan aspek kemenarikan dengan substansi materi. Kegiatan pelatihan penulisan skenario dan pihak-pihak pengambil keputusan terhadap skenario sangatlah penting untuk dilakukan. Begitu pula mencontoh program yang ditayangkan TV atau mengadopsi produk asing merupakan upaya positif menuju sikap dinamis dalam mewujudkan program TV pendidikan/pembelajaran yang tidak hanya sebagai tontonan menarik tetapi juga sebuah tuntunan yang barokah. ${ }^{* *}$ 


\section{DAFTAR PUSTAKA}

Anwas, Oos M. (2005). Sinetron Bukan Hanya Mimpi; Setitik Air di Padang Pasir, Majalah Gemari, Jakarta: edisi Januari.

Association for Education Communication and Technology. Evaluating Media Programs; District and School. Washinton DC.

Iskandar, Eddy D. (1999). Panduan Praktis Menulis Naskah Skenario. Bandung: Remaja Rosda karya.

Jarot, Eross. (2002). Skenario adalah Jatung Film, dalam Akubaca. Jakarta: Yayasan akubaca, Newsletter No. 03 Oktober 2003.

Littlejohn, Stephen W. (1996), Theories of Human Communication, Publishing Company an International, Thomson Publishing Company.

Mc Quail, Denis. (1997). Teori Komunikasi Massa, edisi Indonesia, Jakarta: Erlangga

Mc Quail, Denis and Sven Windahl. (1996), Communication Models; for the Study of Mass Communication, Longman Singapore Publishing.

Murahimin, Ismail. (1994). Menulis Secara Populer, Bandung: remaja Rosda Karya.

Wilkinson, Gene L. (1984). Media dalam Pembelajaran; Penelitian Selama 60 Tahun. Jakarta: Rajawali.

Sendjaja, Sasa Djuarsa (1999). Beberapa Pokok Pikiran tentang Media Televisi vs Buku. Makalah Jurnal Teknodik, Jakarta: Depdiknas Wardhana, Veven Sp. (2001), Televisi dan Prasangka Budaya Massa, Yogyakarta: Galang Printika. 